\title{
Framing effects on fear of terrorism and willingness to sacrifice civil liberties
}

\author{
Ellory Ruth Dabbs \\ West Virginia University, erd0007@mix.wvu.edu
}

Follow this and additional works at: https://researchrepository.wvu.edu/etd

Part of the Other Sociology Commons, and the Race and Ethnicity Commons

\section{Recommended Citation \\ Dabbs, Ellory Ruth, "Framing effects on fear of terrorism and willingness to sacrifice civil liberties" (2019). Graduate Theses, Dissertations, and Problem Reports. 3893. \\ https://researchrepository.wvu.edu/etd/3893 \\ This Thesis is protected by copyright and/or related rights. It has been brought to you by the The Research Repository @ WVU with permission from the rights-holder(s). You are free to use this Thesis in any way that is permitted by the copyright and related rights legislation that applies to your use. For other uses you must obtain permission from the rights-holder(s) directly, unless additional rights are indicated by a Creative Commons license in the record and/ or on the work itself. This Thesis has been accepted for inclusion in WVU Graduate Theses, Dissertations, and Problem Reports collection by an authorized administrator of The Research Repository @ WVU. For more information, please contact researchrepository@mail.wvu.edu.}


2019

Framing effects on fear of terrorism and willingness to sacrifice civil liberties

Ellory Ruth Dabbs

Follow this and additional works at: https://researchrepository.wvu.edu/etd

Part of the Other Sociology Commons, and the Race and Ethnicity Commons 
Framing effects on fear of terrorism and willingness to sacrifice civil liberties

\section{Ellory Dabbs}

Thesis submitted to the Eberly College of the Arts and Sciences at West Virginia University As partial fulfilment of the requirements for the degree of
Master of Arts in Sociology

Joshua Woods, Ph.D., Chair

Christopher P. Scheitle, Ph.D.

Jason Manning, Ph.D.

Department of Sociology and Anthropology

Morgantown, West Virginia

2019

Keywords: terrorism, framing, news, media, vignette experiment, civil liberties, perceptions of violence

Copyright 2019 Ellory Dabbs 


\begin{abstract}
Framing effects on fear of terrorism and willingness to sacrifice civil liberties

Ellory Dabbs
\end{abstract}

The purpose of this research was to determine whether differences in the way the media frames an act of violence leads to different reactions by consumers. In particular, it was hypothesized that the ideology and race of the perpetrator would lead to differences in perceptions of whether or not the attack was terrorism. A vignette-style experiment was performed using respondents recruited via MTurk. Four versions of the vignette were evenly distributed to 441 respondents, changing whether the frame contained a photo, the ideology, and the name of the perpetrator. Using measures of fear from this data it was then investigated whether or not fear made respondents more willing to trade their civil liberties for a feeling of increased security. Though few significant findings were discovered in this research, it is believed that the findings will contribute to the broader topic by suggesting new directions for terrorism and media framing research in the future 


\section{Table of Contents}

Title

Abstract

Table of Contents

Introduction

Literature Review

Framing techniques

Framing after 9/11

Constructing the Enemy

Counterterrorism Policies after 9/11

Entrapment in Counterterrorism Efforts

Punishing the 'Enemy'

Methodology

Data Collection

Dependent Variables

Independent Variables

Control Variables

Table 1: Demographic Distribution of Respondents 14

Analytic Strategy

Table 2: Descriptive Statistics of Variables Used in Analysis 17

Results/Discussion

Table 3: T-tests for Significant Difference in Mean Values of Fear

Table 4: Correlations for Measures of Fear and Willingness to Give

Up Civil Liberties

Table 5: T-tests for Significant Difference in Mean Values of Supporting the F.B.I. Sting Described in the Vignette

Conclusions and Directions for Future Research 


\section{Introduction}

Essentially from birth, humans are exposed to the media, a powerful tool that can be used to shape people's perceptions of social issues. Exposure is nearly impossible to avoid in modern society; for this reason, it is important to understand how the media affects its audience.

Many types of stories, even when proven false, stick with people. False images portrayed on the news lead to misconceptions about threats, leading its audience to place emphasis on 'problems' that are not an actual threat (Slone 2000; Nellis and Savage 2012). The media consistently covers brutal violence and provokes emotional responses from its viewers; depending on how they are framed, these stories cause consumers to feel scared for themselves and for the wellbeing of their loved ones (Slone 2000; Nellis and Savage 2012).

The overall effect of media coverage of violence has been studied by several scholars, especially when that violence can be considered terrorism. Terrorism is likely to gain media attention; according to Surette et. al (2009:360), “...terrorist acts are more likely to receive media coverage if they follow the canons of television entertainment and newsworthinessscarcity, unexpectedness, hostility to elite people or nations, violence, intensity, and unambiguity." However, coverage of terrorist attacks also leads to "dehumanizing the enemy" (Steuter and Wills 2010:152). Dehumanizing the enemy leads to prejudices against different groups of people (Das et. al 2009). News reporters use dehumanizing language to disconnect their viewers from the "enemy" furthering the gap between "us" and "them" (Das et. al 2009; Steuter and Wills 2010; Powell 2018). When the enemy looks different than "us," it is easier to call for harsh punishment. All of these points considered, the media is influential in constructing public opinions that will ultimately influence anti-terrorism policy. 
The goal of this framing-effects study is to determine how different news frames concerning an attempted terrorist attack contribute to changing perceptions amongst readers. Additionally, this framing-effects study will seek to determine how a news frame influences different reactions from readers and their demands for anti-terrorism policy. Using a vignettestyle experiment, readers will be exposed to different frames of essentially the same story. Two of the vignettes will contain a picture, and two will not. Two versions will be framed around an attempted attack by a perpetrator acting for ISIS, and the other two will be framed around an attack by a perpetrator acting for a neo-Nazi group. Following, they will be prompted to answer questions related to the article to determine their views about fear of terrorism and civil liberties

tradeoffs. The overarching goal comes in two parts: first, to understand whether a photo makes a difference in the vignette; second, to understand whether fear leads to willingness to support anti-terror policies that will exchange civil liberties freedoms for an increased feeling of security.

\section{Framing Techniques}

Important in influencing public fear is how a story is framed in the media. A frame is a tool used in the media to construct a story. According to Woods (2011:201), “...frames...exist first of all as words, images, and symbols that appear on paper and in other media." Frames are not one key word, image, or phrase; they depend on the social context and the purpose of the story. Additionally, a frame can extend beyond just one story; frames can cover an entire issue, a prolonged event, a social leader, etc. (Entman 2004). If a frame does not have "magnitude," an aspect that is shocking enough to draw readers in, it will not be successful in sticking around; thus, the most notable frames will be able to stay with its readers and have lasting impact (Entman 2004:31). 
A news frame is how the journalist constructs their story. According to Scheufele (1999:109), journalists consider several factors when constructing a frame, including “...social norms, values, organizational pressures and constraints, pressures of interest groups, journalistic routines, and ideological or political orientations...” Therefore, a journalist does not sadistically construct a frame to be misleading, but rather, they construct a frame based on the context of the period. Journalists want their story to be a success, and they must use techniques that will draw readers in. According to Woods and Marciniak (2016:3), "some words, phrases, symbols, and images are thought to evoke emotions, engage cognition, and access memories in ways that others do not." This makes the story more interesting and leaves a lasting impact.

The influence of a frame is very powerful. A change of one word or phrase can influence the whole interpretation of a story; therefore, it is important to take great care when constructing a frame. The differences can be subtle, and the story can still influence its readers (Nellis and Savage 2012; Woods 2012). These differences could include how one describes a victim, attack, who is at risk, etc. People tend to worry more when an article is framed with the idea that they, or someone they love, is at great risk of attack (Nellis and Savage 2012). Thus, exposure to the same types of framing techniques can change people's perceptions in ways that give them a less accurate view of the world, especially if their knowledge on the topic is limited or misinformed.

Especially influential in a frame are the images it contains. As stated by Brinson and Stohl (2012:273), “...the media help provide us with the images we hold in our heads about the world around us.” According to Bendelow (1993), “...images tend to prompt fast, yet often detailed responses. Responses to visual imagery may be more immediate than responses to textual or other vignette forms..." (Hughes and Huby 2004:41). Because frames that contain 
images have been found to provoke greater responses, the following hypothesis will be investigated:

$\mathrm{H}_{1}$ : A vignette containing a photo will increase fear compared to a vignette containing no photo.

\section{Framing after 9/11}

The lasting effects of media framing can be illustrated by reviewing the literature on post9/11 media framing. These attacks were a shock to the nation and had a great deal of magnitude; therefore, the media actively covered them. (Entman 2004; Jorndrup 2016). Because of the unexpected magnitude of the event, the aftermath of $9 / 11$ framing can still be observed today, and likely had a role in influencing modern attitudes toward terrorism and civil liberties tradeoffs.

The terror attacks on September 11, 2001, reminded the citizens of the United States that the country was not invincible and that terror attacks could lead to mass destruction. It was the overall attitude that those who committed the attacks were evil, and they needed to be dealt with (Entman 2004). The enemy was constructed as Middle Eastern terrorists, and they presented a clear and present danger. It was at this time that President George W. Bush started uttering words such as the "axis of evil" and the "war on terror," which were found in many news articles (Azpiroz 2012:192; Entman 2004:107). Despite the fact that there was no real proof of a continued threat of international terrorism, the president continued to frame the event as such, with the help of the media, and within days Congress unanimously approved military action in the Middle East. This new war was seen as necessary, and even as "retaliatory" on the terrorists that ripped the nation apart (Steuter and Wills 2010). 
Though there was criticism and talk that Bush was overreacting, those concerns were not generally accepted or broadcasted (Woods 2012). And Congress was not the only entity to approve of military action; the public overwhelmingly approved of war more than ever in history and values shifted toward support for military action and spending (Woods 2012). Additionally, most people were willing to give up some of their freedoms and civil liberties to feel more secure. For this reason, one could be led to believe that fear makes people more likely to respond positively to policies that take away freedoms if it makes them feel safe. Based on this, the following hypothesis will be investigated:

$\mathrm{H}_{2}$ : The more fearful people are, the more willing they will be to give up civil liberties rights for a feeling of increased security.

\section{Constructing the Enemy}

These post-9/11 attitudes led to writing that "dehumanized the enemy" (Steuter and Wills 2010:156). Journalists and politicians refer to Muslim people and terrorists alike as animals, vermin, and monsters, that need to be hunted, trapped, and killed (Steuter and Wills 2010; Powell 2018). This kind of language, according to Steuter and Wills (2012:164), “create[s] feardriven and inappropriate responses that...might lure the public into disregarding due process of the law." These fearful responses to news coverage could have an impact on how people view the "enemy" and correspondingly increase public support for policies that reduce civil liberties, especially when it comes to those who are descended from the Middle East.

Acts of violence are much more likely to quickly be labeled as terrorism if the perpetrator is descended from the Middle East without looking into the suspect's motivations or nationality (Powell 2018). Even if the person was a U.S. citizen, the media is quick to link someone who looks Muslim to terrorism than someone who does not. Additionally, because of post-9/11 news 
framing techniques, people are often unsure what the difference between those who are radical Islamists and those who just practice the Islamic religion. This leads to the impression that “...the actions of one Muslim are equated to all Muslims" (Powell 2018:2). This leads to reactions from the public that reinforce stereotypes.

If the perpetrator of a mass act of violence does not fit the look of your 'standard' terrorist, the media is careful in their framing. It is only when they have looked into the person's relationships, international ties, mental health background, etc., that this person is labeled a terrorist (Powell 2018). Journalists hesitate in labeling acts as domestic terrorism and often try to pin the attack on the personality of the perpetrator-typically describing the attacker as a "loner" (Powell 2018). Additionally, even if the act fell under what would be considered terrorism, the media rarely labeled it as such unless the perpetrator was found to have pledged allegiance to some international terrorist group (Powell 2018). Thus, based on the preceding information, the following hypothesis was developed:

$\mathrm{H}_{3}$ : The ISIS frame will increase fear compared to the neo-Nazi frame.

\section{Counterterrorism Policies After 9/11}

Summarizing the literature up to this point, post-9/11 news frames have led people to be fearful of terrorism and prejudiced against those descended from the Middle East. The media is far more likely to label an act of mass violence as terrorism if the perpetrator is of Middle Eastern descent, and often avoids labeling an act of mass violence as terrorism if they can avoid it for white perpetrators. For this reason, politicians have been able to enact new policies and procedures that might overestimate the problem of terrorism and lead to differential treatment of different racial and religious groups. These policies often focus on "international" rather than "domestic" cases of terrorism, causing the public to fear the wrong thing (Brinson and Stohl 
2012:272). After the attacks of 9/11, leaders took steps to enact preventative measures against future attacks from "outsiders."

Several counter-terrorism methods were introduced after $9 / 11$. One of the most shocking is the preemptive measures authorities are able to take to 'prevent' terrorism before it can happen. According to De Lint and Kassa (2015:354), “Government officials portray the threat of terrorist attacks as both immediate and of great magnitude." This kind of portrayal of the threat brings about a feeling of "moral panic" where the public feels defensive of their values (De Lint and Kassa 2015:354). According to Welch (2015:4), "since 9/11, the public has demonstrated considerable support for harsh national policies aimed at preventing terrorism and punishing suspected terrorists." Therefore, there is a demand from the public to continue spending on counter terrorism policies and to be diligent in terrorism prevention.

But counter terrorism policies have serious implications for the citizens of the United States. Supporters of counter terrorism policies often have the attitude that the government should do what it must to prevent terrorism; however, they do not always realize the implications these policies have for both their own freedoms and the freedoms of American minorities (Viscusi and Zekhauser 2003). Studies have shown that people are far more likely to support counterterrorism policies if they view people from the Middle East as the would-be terrorists (Viscusi and Zekhauser 2003; Welch 2015). When people are faced with making decisions about terrorism policy, it has been found that unless they perceive themselves as being directly impacted, they are supportive of policies that would potentially take away some of their own civil liberties rights. Consider airport searches after 9/11. In a study done by Viscusi and Zekhauser (2003:104), evidence was found that respondents were more likely to support "targeted airport searches" if it reduced their own personal wait times. However, when faced 
with the question of supporting a policy of general airport searches, the respondents were much less likely to be in favor. This fact is also illustrated when Viscusi and Zekhauser (2003:107) asked respondents if they would support policy that allowed the government to essentially "snoop" on emails, phone calls, etc., of anyone they suspected of terrorism. This is because the policy would not be targeting a particular group of people, rather, the general public as a whole.

Those who are likely to stereotype a terrorist as being of Middle Eastern descent are more likely to support punitive policies (Welch 2015). If these people are fearful of terrorism in general, and are believing that terrorists are coming from a specific minority group, then it is likely they will support policies that will take away some of their civil liberties rights. This is because they probably believe that since they are not terrorists, they will not be impacted by antiterror policies, other than being kept safer. From this literature, the following hypothesis was developed:

$\mathrm{H}_{4}$ : The ISIS frame will increase willingness to trade security for civil liberties.

\section{Entrapment in Counterterrorism Efforts}

The policy focused on in this paper is entrapment. The F.B.I. has been involved in several stings to catch terrorists before they strike. These "pre-crime" practices are designed, as stated, to stop terrorist attacks before they happen (De Lint and Kassa 2015:361). However, critics argue that these "pre-crime" tactics are not useful in preventing would-be terror attacks, but rather, they “manufacture synthetic terrorists" (De Lint and Kassa 2015:361). De Lint and Kassa (2015) state that most of the big terrorism plots since $9 / 11$ were actually built by the F.B.I.; the F.B.I. tracks down people who they think could possibly commit an act of terrorism and guide them along.

It is important to understand how these F.B.I. stings work. As explained by Aaronson (2013:2): “. ...the F.B.I. uses one of its more than 15,000 registered informants - many of them 
criminals, others trying to stay in the country following immigration violations - to identify potential terrorists. It then provides the means necessary for these would-be terrorists to move forward with a plot—in some cases even planting specific ideas for attacks." The subject of these stings is offered money, weapons, and anything they would need to commit the act by the F.B.I. (Norris and Grol-Prokopczyk 2018). However, they never actually get anything concrete. The informants, on the other hand, are compensated monetarily—often in large sums.

There is a major flaw in these terrorism stings, however. Aaronson (2013) explains that when the F.B.I. performed drug bust stings, they could be certain that the subjects would have access to drugs without the help of the F.B.I. If they did not engage in criminal activity at the site that the F.B.I. created, they could easily find somewhere nearby to acquire the materials. However, this is not likely in terrorism stings. Aaronson (2013:4) states, "In terrorism stings...federal law enforcement officials assume that any would-be terrorists caught would have been able to acquire the means elsewhere to carry out their violent plans had they not been ensnared by the F.B.I. The problem with this assumption is that no data exists to support it—and in fact what data is available often suggests the opposite." The subject of an F.B.I. sting is often mentally incapable of orchestrating an attack without help - and if an attack actually is successfully planned, usually the person fails before they meet their goal (Aaronson 2013; De Lint and Kassa 2015; Norris and Grol-Prokopczyk 2018). Additionally, the subjects do not typically fit the description of your 'average' terrorist—smart, ideological, etc., — suggesting that they would be even more unlikely to commit an act of terror (Aaronson 2015). 


\section{Punishing the 'Enemy'}

So, who are these would be terrorists? They come in all shapes and sizes, but, unsurprisingly, they are not dealt with in a universal way. Two types of terrorism will be considered in this paper- - "right wing" terrorism and "neojihadi" terrorism (Norris and GrolProkopczyk 2018). Right wing terrorism acts motivated by far-right ideologies; white supremacist movements, anti-government movements, etc. (Norris and Grol-Prokopczyk 2018). Neojihadi acts are the more commonly thought of acts - those committed (apparently) in the name of radical Islam. However, it is important to note that just because a person says an act is in the name of Islam does not mean that those who practice the religion agree with it.

Brinson and Stohl (2012) stated that frames can activate different schemas depending on the content. This could include domestic versus international terrorism, or right wing versus neojihadi terrorism. Norris and Grol-Prokopczyk (2018) were interested to know the differences in right wing entrapment versus neojihadist entrapment. In order to study this phenomenon, the authors use a mixed methods approach. They quantitatively review a database of post-9/11 terrorism cases encompassing terrorism prosecutions including an informant from 2011-2014. According to Norris and Grol-Prokopczyk (2018), "The database includes 68 right-wing prosecutions, 190 neojihadi prosecutions, and 13 left-wing prosecutions, yielding a total of 271 cases in our analyses." They conducted statistical tests to create entrapment scores for each case, then chose the top five right-wing entrapment cases to review quantitatively. They found that overall, claims of entrapment were less likely in right-wing terrorism cases. When entrapment was found, the conditions were less harsh than in neojihadist cases.

These findings suggest that entrapment is less likely to occur in right-wing terrorism cases, and if it does, the methods used to prosecute will not be as severe. It is important to note 
that right-wing terrorists are often white men of privilege. In other cases of terrorism, the perpetrator is often a disadvantaged minority (Norris and Grol-Prokopczyk 2018). Because rightwing terrorism cases are less likely to be orchestrated, and because people from the Middle East are often framed in dehumanizing ways, it could be assumed that just by looking at a perpetrator who fits the look of either type of terrorist could cause the public to react in different ways to the same actions by the F.B.I. Assuming that a picture does make a difference and does increase fear, respondents should be more likely to view the vignettes without photos more critical of the F.B.I.'s actions, and to be more supportive of the F.B.I.'s practices in the vignettes with photos. Thus, the final hypothesis will be tested:

$\mathrm{H}_{5}$ : A vignette containing a photo will increase willingness to trade security for civil liberties.

It is important for the public to understand this counter terrorism practice and its effectiveness. Overall, De Lint and Kassa (2015) conclude that counter terrorism practices are only worthwhile if they are examined at face value. It might be true that the authorities are 'catching' a lot of terrorists, but in reality, on 25 percent of cases believed to be terrorism are prosecuted as such (De Lint and Kassa 2015). This will lead to misconceptions about who is likely to be a terrorist, how effective counterterrorism really is, and what kind of methods we should be allowed to use to catch terrorists.

\section{Methodology}

The present study will utilize a vignette-style survey to best understand the public's reactions to news stories about an attempted act of terrorism. A vignette is "text, images, or other forms of stimuli to which research participants are asked to respond" (Hughes and Huby 2004). This type of survey presents different versions of the same story to readers but changes the 
stimuli. Following, respondents are asked questions not only to check their understanding of the article, but also to measure their views and opinions about different topics. If significant differences are found, then it is hypothesized that the different versions of the vignette affect the readers differently.

This study used four different vignettes about an attempted bombing at a shopping mall on black Friday, one of the busiest shopping days of the year. In the article, the perpetrator was assisted by an F.B.I. informant to further his goal of gaining the attention of some extremist group. Before the suspect actually could go through with the act of mass violence, the F.B.I. arrested him. The article concludes with a statement that the defense attorney was seeking an entrapment case, stating that the man could not have gone through with the act without the help of the F.B.I. The stimuli that changed in the vignette were the perpetrator's name, the group the perpetrator was trying to catch the attention of, and whether there was a picture with the article or not. Version one of the vignettes contained no picture, the perpetrator's name was Hassan Najjar, and he was motivated to gain the attention of ISIS. The second vignette was the same, except it contained a picture of a man who looked to be of Middle Eastern descent—dark skin, dark hair, and dark eyes. Version three of the vignettes contained no picture, the perpetrator's name was James Fields, and he was looking to gain the attention of the neo-Nazi Skinheads. Version four was identical to version three, except that it contained a picture of a white male with blue eyes and blonde hair.

\section{Data Collection}

Data was collected through Amazon Mechanical Turk (MTurk). MTurk is a quick and simple way to gain a relatively diverse sample. According to MTurk's website, "The MTurk web service enables companies to programmatically access this marketplace and a diverse, on- 
demand workforce. Developers can leverage this service to build human intelligence directly into their applications" (mturk.com 2019). Data collected via MTurk has been found in the past to be about as reliable as data collected using other measures; however, reliable data does not mean that the participants will be representative of the population (McDuffie 2019). According to McDuffie (2019), "MTurk can be a great means of recruiting a diverse sample quickly and in a cost-efficient manner; however, the inherent differences observed between an MTurk sample and a sample collected using traditional methods might present significant challenges in generalizing the results of the study." Thus, even though the data collected might not be as generalizable as collecting data from a more diverse sample, MTurk was the best way to collect data for this project. Any issues with the specific data collected for this project is addressed in the limitations section of this paper.

The survey was uploaded to MTurk directly from Qualtrics, an online survey platform. Using Qualtrics, four different versions of the survey were created and distributed evenly to 441 respondents. A summary of demographic variables collected is included in Table 1.

\section{Dependent Variables}

Two dependent variables were examined in this project. The first was fear. Fear was measured by asking respondents two questions — one about how likely the respondent thought a future attack was, and one about how worried the respondent was about the possibility of a future attack. Both questions asked the respondent to rate their response on a seven-point scale, with one being "extremely unlikely" and seven being "extremely likely." The higher on the response scale, the more fearful that respondent was assumed to be.

The second dependent variable was willingness to trade civil liberties for a feeling of increased security. This was measured in two ways - first, by asking several questions about 
what the respondent thought of the F.B.I.'s actions in the vignette, and second, by asking the respondent directly about whether they would be willing to support policies that would make them lose some of their civil liberties. It was hypothesized that willingness to trade civil liberties would depend on their views of the vignette.

\section{Independent Variables}

The primary independent variable for analyses on fear was what treatment/vignette the respondent was assigned to. The first stimuli considered was the "package" of the race/ideology of the perpetrator (Middle Eastern/ISIS or White/neo-Nazi). The other primary independent variable for fear with whether or not the vignette contained a photo. These variables were hypothesized to cause differences in the dependent variables.

When considering the civil liberties hypotheses, the measures for fear became the primary independent variable, as it was hypothesized that the more fearful a respondent is, the more likely it is that they will be willing to sacrifice civil liberties for increased security.

\section{Control Variables}

The remaining independent variables were included based on their influence on fear identified in prior research. These are summarized in Table 1, along with a summary of sample demographic characteristics.

Table 1: Demographic Distribution of Respondents

\begin{tabular}{lcccccc}
\hline & N & Percent & Mean & SD & Min & Max \\
\hline Gender & 440 & & & & & \\
Male & 233 & 53 & & & & \\
Female & 207 & 47 & & & & \\
& & & & & & \\
Age & 439 & & 38.3 & 23 & 18 & 77 \\
$18-24$ & 28 & 6.40 & & & & \\
$25-34$ & 203 & 46.2 & & & & \\
$35-44$ & 104 & 23.7 & & & & \\
$45-54$ & 50 & 11.4 & & & &
\end{tabular}


55-64

65 or older

Race

Black, African, Caribbean

Caucasian, White, European

Central Asian/Arab

East Asian (Chinese, Japanese,

Korean, Taiwanese, etc.)

South Asian (Indian, Pakistani,

Bangladeshi, etc.)

Hispanic/Latino/Latina

Other

Education

Less than high school

High school

Associate's degree

Bachelor's degree

Master's degree

Professional degree/Doctorate

Citizenship

I am a citizen of another country, not the U.S.

I was not born in the US, but I am a US citizen

I was born in the US, but one of my parents was born in another country

I was born in the US, but both of my parents were born in another country

I was born in the US and both of my parents were born in the US

Political Ideology

Political Party

Republican

Democrat

Independent

Not affiliated with a political party

Something Else
$41 \quad 9.30$

$13 \quad 3.0$

$37 \quad 8.4$

$348 \quad 79.1$

$\begin{array}{ll}3 & 0.7\end{array}$

$25 \quad 5.7$

$\begin{array}{ll}4 & 0.9\end{array}$

$9 \quad 2.0$

$14 \quad 3.2$

440

$\begin{array}{ll}3 & 0.7\end{array}$

$85 \quad 19.3$

$\begin{array}{ll}68 & 15.4\end{array}$

21148

$59 \quad 13.4$

$14 \quad 3.2$

440

$14 \quad 3.20$

$24 \quad 5.40$

$28 \quad 6.40$

$26 \quad 5.90$

$248 \quad 79.10$

439

$\begin{array}{llll}4.60 & 1.80 & 1.0 & 7.0\end{array}$

440

$118 \quad 26.8$

$209 \quad 47.5$

$103 \quad 23.4$

$5 \quad 1.10$

$5 \quad 1.10$ 


\section{Analytic Strategy}

After viewing the vignette and answering initial questions gauging the respondents' reaction, respondents were asked questions to measure how well they comprehended the vignettes they read. Overall, the majority of respondents seemed to understand the vignette. However, a lower percentage than desired answered correctly, with only 75 percent $(\mathrm{N}=332)$ of respondents identifying the correct weapon used in the vignette. 81 percent $(\mathrm{N}=180)$ of the respondents assigned to the ISIS treatment correctly identified the ideological motivation of the offender, and 85 percent $(\mathrm{N}=185)$ of the respondents assigned to the neo-Nazi treatment correctly identified the motivation of the offender in the vignette.

Table 2 provides descriptive statistics for the main variables measured. Though the descriptive statistics were telling of the results, further analyses were performed to confirm whether the findings were significant or not. Hypotheses 1 and 3 were concerned with differences in treatments. The study sought to determine whether frames made a difference in the responses to questions that measured fear. To determine whether differences were significant multiple t-tests were performed. New dummy variables were created to represent the groups being tested. Hypothesis 1 and hypothesis 5 concerned comparing a vignette containing a photo against a vignette containing no photo; therefore, a variable was created where 1 represented a treatment with a photo and 0 represented a treatment with no photo. Hypothesis 3 and hypothesis 4 were aimed to compare the ISIS frame against the neo-Nazi frame; therefore, a dummy variable was created where 1 represented the ISIS treatment and 0 represented the neoNazi treatment. Both measures of fear, how worried the respondent was and how likely they thought a future attack was, were used in the t-tests for hypothesis 1 and 3 . Both of the results of these tests are summarized in Table 3. To test hypothesis 4 and 5, which concerned civil liberties 
rather than fear, differences were tested using dummy variables created to represent questions about the F.B.I.'s involvement in the story, rather than how fearful the respondents were. These results are summarized in Table 5.

To determine whether fear influenced civil liberties tradeoffs, as described in hypothesis 2 , several ordinary least squares regression analyses were performed at the bivariate level. Table 5 summarizes the results of these analyses and their significance.

Table 2 Descriptive Statistics of Variables used in Analysis

\begin{tabular}{lccccc}
\hline \multicolumn{1}{c}{ Variable } & N & Mean & SD & Min & Max \\
\hline Dependent Variables & & & & & \\
\hline Fear & & & & & \\
Worry & 441 & 4.52 & 1.75 & 1 & 7 \\
Likeliness of future attack & 441 & 4.62 & 1.56 & 1 & 7 \\
\hline Civil Liberties & & & & & \\
\hline F.B.I Was right to organize sting & 441 & 4.0 & 1.0 & 1 & 5 \\
The F.B.I's actions are entrapment & 441 & 2.72 & 1.2 & 1 & 5 \\
Freedom & 441 & 3.84 & 1.81 & 1 & 7 \\
New law & 441 & 4.19 & 1.68 & 1 & 7 \\
Wiretap Phones & 441 & 2.73 & 1.19 & 1 & 5 \\
Intercept Emails & 440 & 2.74 & 1.24 & 1 & 5 \\
Examine Internet Activities & 441 & 3.0 & 1.3 & 1 & 5 \\
Detain Suspect Indefinitely & 441 & 2.6 & 1.18 & 1 & 5 \\
\hline Independent Variables & & & & & \\
Photo(worry) & 215 & 4.58 & 1.76 & 1 & 7 \\
Photo(likely) & 215 & 4.72 & 1.55 & 1 & 7 \\
\hline
\end{tabular}

\section{Results/Discussion}

The first hypothesis, that a vignette containing a photo will increase fear compared to a vignette containing no photo, was not supported for either of the variables that were designed to measure fear. For this hypothesis to be supported, we would have expected the mean for a vignette containing a photo to be significantly greater than the mean for a vignette containing no photo $($ Ha: diff $<0)$. Although the means of the vignette containing a photo is greater for both 
how worried the respondent is and how likely they think a future attack is, the t-test did not support its significance. It is reassuring that the means differ in the right direction, and perhaps with a greater sample they would have been found to be significant.

Hypothesis 3, that the ISIS frame would increase fear compared to the neo-Nazi frame, was also not supported for either of the variables measuring fear. In fact, the means did not even move in the right direction, suggesting that the neo-Nazi frame had a greater impact on the respondent's fearful reaction. This is interesting, because no previous literature has suggested this finding. However, in the last few years, there have been several acts of mass violence that were committed by white supremacists. It is plausible that since acts of terrorism committed by ISIS are not as common in the media at this juncture that people are more worried about what they think is most likely to occur. But the means were barely different on the variable measuring worry about an attack, and they were not significantly different. Perhaps a greater, more diverse sample would have produced different results, but it is doubtful. There was more support for the assumption, not originally hypothesized in this paper, that people are more likely to be fearful of neo-Nazi acts when one only considers how likely respondents thought an attack was. There was significant support for differences in means going the opposite direction than hypothesized, meaning that the mean for the variable measuring fear was higher for the neo-Nazi frame. This is completely opposite of the hypothesis presented in this paper $(\mathrm{H}: \mathrm{a} \operatorname{diff}>0 ; \mathrm{p}=0.05)$. This suggests that people are far more likely to believe that an attack done by a neo-Nazi is likely in the future. 
Table 3: T-tests for Significant Difference in Mean Values of Fear

\begin{tabular}{lccccc}
\hline \multicolumn{1}{c}{ Group } & & & & \multicolumn{2}{c}{$\begin{array}{c}\text { p-value } \\
\text { (Ha: diff } \\
<0)\end{array}$} \\
\hline Photo Differences (worry) & N & Mean & SE & SD & $<0.24$ \\
No Photo & $\mathbf{4 4 1}$ & & & & $\mathbf{0 . 2 4}$ \\
Photo & 226 & 4.46 & 0.12 & 1.75 & \\
Photo Differences (likely) & 215 & 4.58 & 0.12 & 1.76 & \\
No photo & $\mathbf{4 4 1}$ & & & & $\mathbf{0 . 0 9}$ \\
Photo & 226 & 4.52 & 0.1 & 1.56 & \\
Ideology Differences (worry) & 215 & 4.72 & 0.11 & 1.55 & \\
neo-Nazi & $\mathbf{4 4 1}$ & & & & $\mathbf{0 . 5 3}$ \\
ISIS & 218 & 4.53 & 0.12 & 1.73 & \\
Ideology Differences (likely) & 223 & 4.52 & 0.12 & 1.78 & \\
neo-Nazi & $\mathbf{4 4 1}$ & & & & $\mathbf{0 . 9 4}$ \\
ISIS & 218 & 4.73 & 0.10 & 1.50 & \\
\hline
\end{tabular}

Hypothesis 2, that the more fearful people are, the more likely they will be to give up civil liberties, was supported and significant for nearly all variables tested, with the exception of the bivariate analysis concerning the relationship between the likelihood of a future attack and willingness to give the government increased authority to wiretap phones and intercept email. The overwhelming pattern is that the more worried respondents were about terrorism, and the more likely they thought at attack was, the more they favored laws and practices that limited their civil liberties rights. However, the variable measuring how likely a future attack produced less significant results than the variable measuring worry. This could be because if a respondent is worried overall about terrorism, they might be more willing to take preventative measures regardless of if they think an attack is likely. Without an immediate threat, respondents might not see the usefulness of supporting policies, in particular wiretapping phones and intercepting emails, if they do not feel that an attack is likely to happen. Additionally, these practices in particular could have just seemed less useful than other ones. The most significant results were 
present in the more vaguely worded questions, such as "To what extent would you support or oppose new laws to strengthen to strengthen security measures against terrorism, even if it meant reducing privacy protections?" and "To what extent would you be willing or unwilling to give up some of your personal freedom in order to reduce the threat of terrorism?" It is plausible that until faced with specific details of what freedoms they are giving up and what these new laws entail that the respondent is more willing to give up freedoms because they do not feel that supporting these laws will affect them. As we move toward defining these laws, fearful respondents are still likely to support them, but they do seem to be a bit more hesitant.

Table 4: Correlations for Measures of Fear and Willingness to Give Up Civil Liberties

\begin{tabular}{|c|c|c|c|c|}
\hline & \multicolumn{2}{|c|}{ Worry $(\mathrm{N}=441)$} & \multicolumn{2}{|c|}{ Likelihood $(\mathrm{N}=441)$} \\
\hline & Unstandardized Coef. & $\mathrm{R}$ & Unstandardized Coef. & $\mathrm{R}$ \\
\hline Freedom & $0.40^{* *}$ & 0.41 & $0.17^{* *}$ & 0.19 \\
\hline New Law & $0.35^{* *}$ & 0.34 & $0.17 * *$ & 0.18 \\
\hline Wiretap & $0.30^{* *}$ & 0.2 & 0.06 & 0.04 \\
\hline Intercept Email & $0.30^{* *}$ & 0.21 & 0.07 & 0.06 \\
\hline Observe Internet activities & $0.39 * *$ & 0.29 & $0.11 *$ & 0.09 \\
\hline $\begin{array}{l}\text { Detain suspect indefinitely } \\
*_{\mathrm{p}}<.05 * * \mathrm{p}<.01\end{array}$ & $0.37 * *$ & 0.25 & $0.14^{*}$ & 0.11 \\
\hline
\end{tabular}

Hypothesis 4, that the ISIS frame will increase willingness to trade security for civil liberties, was not supported, with nearly identical means found. Hypothesis 5 , that a vignette containing a photo will increase respondents' willingness to give up civil liberties, was not supported. The means also were nearly identical, indicating that a photo had no effect on respondent reactions regarding civil liberties rights.

Overall, it seems that terrorism of any kind results in respondents being more supportive of increased F.B.I. action. The questions measuring support for the practices were "How much do you agree or disagree with the following statement: the F.B.I. was right to organize the sting 
operation described in this article?" 43 percent of respondents $(\mathrm{N}=189)$ agreed with this statement, and 35 percent $(\mathrm{N}=153)$ strongly agreed. The other question measuring support for the F.B.I. practices focused on entrapment, asking the respondents, "How much do you agree or disagree with the following statement: the F.B.I's sting operation described in the article should be classified as entrapment (helping the suspect commit a crime)?" 36 percent disagreed with the statement, 15percent strongly disagreed, and 19 percent neither agreed nor disagreed. Though these results are more evenly distributed, they still indicate that over half of the respondents would support practices that are intrusive of their civil liberties rights.

These results are consistent with the findings from investigating hypothesis 3 , and what seems to be the overwhelming results of this study—if respondents are fearful of terrorism, they will be more supportive of policies that restrict civil liberties freedoms. Framing does not seem to make much of a difference.

Table 5: T-tests for Significant Difference in Mean Values of Supporting the F.B.I. Sting Described in the Vignette

\begin{tabular}{lccccc}
\hline \multicolumn{1}{c}{ Group } & N & Mean & SE & SD & p-value \\
\hline Photo Differences (sting) & $\mathbf{4 4 1}$ & & & & $\mathbf{0 . 6 3}$ \\
No Photo & 226 & 4.0 & 0.06 & 0.97 & \\
Photo & 215 & 3.98 & 0.07 & 1.0 & \\
Photo Differences (entrap) & $\mathbf{4 4 1}$ & & & & $\mathbf{0 . 4 3}$ \\
No photo & 226 & 2.70 & 0.08 & 1.23 & \\
Photo & 215 & 2.73 & 0.08 & 1.17 & \\
\hline Ideology Differences (sting) & $\mathbf{4 4 1}$ & & & & \\
neo-Nazi & 223 & 4.0 & 0.07 & 0.97 & $\mathbf{0 . 6 3}$ \\
ISIS & 218 & 4.0 & 0.07 & 1.0 & \\
Ideology Differences (entrap) & $\mathbf{4 4 1}$ & & & & $\mathbf{0 . 4 8}$ \\
neo-Nazi & 218 & 2.71 & 0.08 & 1.19 & \\
ISIS & 223 & 2.72 & 0.08 & 1.20 & \\
\hline
\end{tabular}




\section{Conclusions and Directions for Future Research}

Though most of the findings in this study were not statistically significant, the results make many implications for future research. First, a photo of the perpetrator's mugshot had no significant effects in this study. Future research projects should consider using a different sort of photo - perhaps one of a crime scene - and measure if that results in different reactions. Though a photo had no effect on a respondent's willingness to sacrifice civil liberties, there was some evidence supporting the idea that a photo could increase fear.

Another interesting suggestion that comes from this research is that people are more likely to fear the neo-Nazi terrorist than the Islamic one. Future research should delve into this idea more to understand whether these results were a one-time occurrence, having to do with the small and fairly liberal sample, or if this is a new trend. As previously suggested, the increased coverage of neo-Nazi terrorism could have an influence on how respondents are thinking about terrorism. After the attacks on September 11, 2001, the media provided numerous stories and images of the attacks, and this was correlated with increased fear of people from the Middle East and Islamic Terrorism. It is possible that we are observing a similar pattern now, but with a different 'enemy' being painted by the media.

There were several limitations to this study. First, because the study utilized an online survey, there was no room for respondents to ask questions about responses they did not fully understand. This could explain the lower percent of manipulation checks answered correctly. Additionally, because the survey was not done face-to-face, there was less pressure for the respondents to take the survey seriously. Although there was a minimum amount of time respondents had to spend reading the vignette, this was not a guarantee that they actually felt that it was important to read the vignette carefully. 
Additionally, the sample was fairly small $(\mathrm{N}=441)$. Though these results are suggestive of possible trends in the public, the sample was not as representative as it could have been. Referring to Table 1, the respondents were mostly white, younger, democrat/liberal, citizens of the United States, and were rather highly educated. Education, age, and a liberal political ideology especially are known to be less fearful. If they are overrepresented in this sample, then that can skew results.

In conclusion, though the results of this study were not as expected, it is still useful in examining the relationship between the media and the public. Several implications for future research come from this study, and perhaps in the future more significant results will prove the original hypotheses were not far from the truth. 
Works Cited

Aaronson, T. (2013). Inside the Terror Factory. [online] Mother Jones. Available at: http://www.motherjones.com/politics/2013/01/terror-factory-fbi-trevor-aaronson-book Azpiroz, Maria Luisa. 2012. "Framing as a tool for mediatic diplomacy analysis: study of George W. Bush's political discourse in the "War on Terror." Communication \& Society 26(2): 176-197.

Beckett, Katherine and Theodore Sasson. 2004. The Politics of Injustice: Crime and Punishment in America. Thousand Oaks, CA: Sage Publications, Inc.

Brinson, Mary E. and Stohl, Michael. 2012. "Media Framing of Terrorism: Implications for Public Opinion, Civil Liberties, and Counterterrorism Policies." Journal of International and Intercultural Communication 5(4): 270-290.

Chiricos, Ted, Sarah Eschholz, and Marc Gertz. 1997. "Crime, News, and Fear of Crime: Toward an Identification of Audience Effects.” Social Problems 44(3): 342-354

Das, Enny, Brad J. Bushman, Marieke D. Bezemer, Peter Kerkhof, Ivar E. Vermeulen. 2009. "How terrorism news reports increase prejudice against outgroups: A terror management account. Journal of Experimental Psychology 45: 453-459.

De Lint, Willem, and Wondwossen Kassa. 2015. "Evaluating U.S. Counterterrorism Policy: Failure, Fraud, or Fruitful Spectacle?" Critical Criminology 23: 349-369.

Entman, Robert. 2004. Projections of Power: Framing News, Public Opinion, and U.S. Foreign Policy. Chicago, IL: The University of Chicago Press.

Hollis, Meghan E., Alex del Carmen, Shareece Downey, and Rhonda R. Dobbs. 2017. “The Relationship Between Media Portrayals and Crime: Perceptions of Fear of Crime Among Citizens.” Crime Prevention and Community Safety 19: 46-60. 
Hughes, Rhidian and Meg Huby. 2004. "The construction and interpretation of vignettes in social research.” Social Work and Social Sciences Review 11(1): 36-51.

Jorndrup, Hanne. 2016. "News Framing in a Time of Terror: A Study of the Media Coverage of the Copenhagen Shootings.” Nordicom Review 37(special issue): 85-99.

McDuffie, Danielle. 2019. Using Amazon's Mechanical Turk: Benefits, Drawbacks, and Suggestions. [online] Association for Psychological Science. Available at: https://www.psychologicalscience.org/observer/using-amazons-mechanical-turk-benefitsdrawbacks-and-suggestions

Nellis, Ashley Marie and Joanne Savage. 2012. "Does Watching the News Affect Fear of Terrorism? The Importance of Media Exposure on Terrorism Fear.” Crime and Delinquency 58(5): 748-468.01

Norris, Jesse J., and Hanna Grol-Prokopczyk. 2018 “Entrapment allegations in right-wing terrorism cases: A mixed methods analysis." International Journal of Law, Crime and Justice 53: 77-88.

Powell, Kimberly A. 2018. "Framing Islam/Creating Fear: An Analysis of U.S. Media Coverage of Terrorism from 2011-2016." Religions 9(257): 1-15.

Scheufele, Dietram A. 1999. "Framing as a Theory of Media Effects." Journal of Communication:103-122

Slone, Michelle. 2000. "Responses to Media Coverage of Terrorism.” Journal of Conflict Resolution 44(4): 502-522.

Steuter, Erin, and Deborah Wills. 2010. “'The Vermin Have Struck Again’: Dehumanizing the Enemy in Post 9/11 Media Representations.” Media, War, \& Conflict 3(2): $152-167$. 
Surette, Ray, Kelly Hansen, and Greg Noble. 2009. "Measuring Media Oriented Terrorism." Journal of Criminal Justice 37: 360-370.

Viscusi, W. Kip, and Richard J. Zeckhauser. 2003. "Sacrificing Civil Liberties to Reduce Terrorism Risks." The Journal of Risk and Uncertainty 22(2/3): 99-120.

Welch, Kelly. 2015. "Middle Eastern Terrorist Stereotypes and Anti-Terror Policy Support: The Effect of Perceived Minority Threat." Race and Justice 1-29.

Woods, Joshua. 2011. "Framing terror: an experimental framing effects study of the perceived threat of terrorism." Critical Studies on Terrorism 4(2): 199-217.

Woods, Joshua. 2012. Freaking Out: A Decade of Living with Terrorism. Dulles, VA: Potomac Books.

Woods, Joshua and Agnieszka Marciniak. 2016. "The Effects of Perceived Threat, Political Orientation, and Framing on Public Reactions to Punitive Immigration Law Enforcement Practices." 2016. Sociology of Race and Ethnicity: 1-16. 
Appendix A: Vignettes

\section{WASHINGTON - ASSOCIATED PRESS}

The F.B.I. has significantly increased its use of stings in investigations, employing agents and informants to pose as an aid in attempted acts of terrorism.

While F.B.I. officials say they are careful to avoid illegally entrapping suspects, their undercover operatives are far from bystanders. In recent investigations F.B.I. agents and informants helped people suspected of being involved in terroristic activity achieve their less than legal goals.

Take, for instance, the case of $<$ James Fields / Hassan Najjar $>$ and the attempted bombing of a shopping mall in Seattle, Washington. <Fields /Najjar $>$ told an FBI informant through online communication that he was interested in carrying out a large-scale attack on Black Friday, one of the busiest shopping days in the United States. When the F.B.I. informant questioned why, $<$ Fields / Najjar $>$ asserted that he wanted to do so to capture the attention of $<$ ISIS / Neo-Nazi Skinheads $>$. Seemingly sympathetic to the cause, the informant said he could introduce $<$ Fields/Najjar $>$ to someone who could assist him but he needed proof that his intentions were genuine.

$<$ Fields /Najjar $>$ wrote a letter swearing allegiance to do whatever it takes to impress $<$ ISIS / Neo-Nazi Skinheads $>$, even if it meant producing mass casualties. The informant agreed that his intentions seemed legitimate and set up a time to meet with the third party to exchange plans and weapons.

$<$ Fields /Najjar $>$ was arrested outside of the designated meeting spot on a charge of attempting an act of terrorism.

Defense attorneys are seeking an entrapment case, stating that $<$ Fields/ Najjar $>$ would not have had the financial or intellectual means to carry out a terrorist attack were it not for the help from the F.B.I. Additionally, $<$ Fields/ Najjar $>$ had no prior record. 

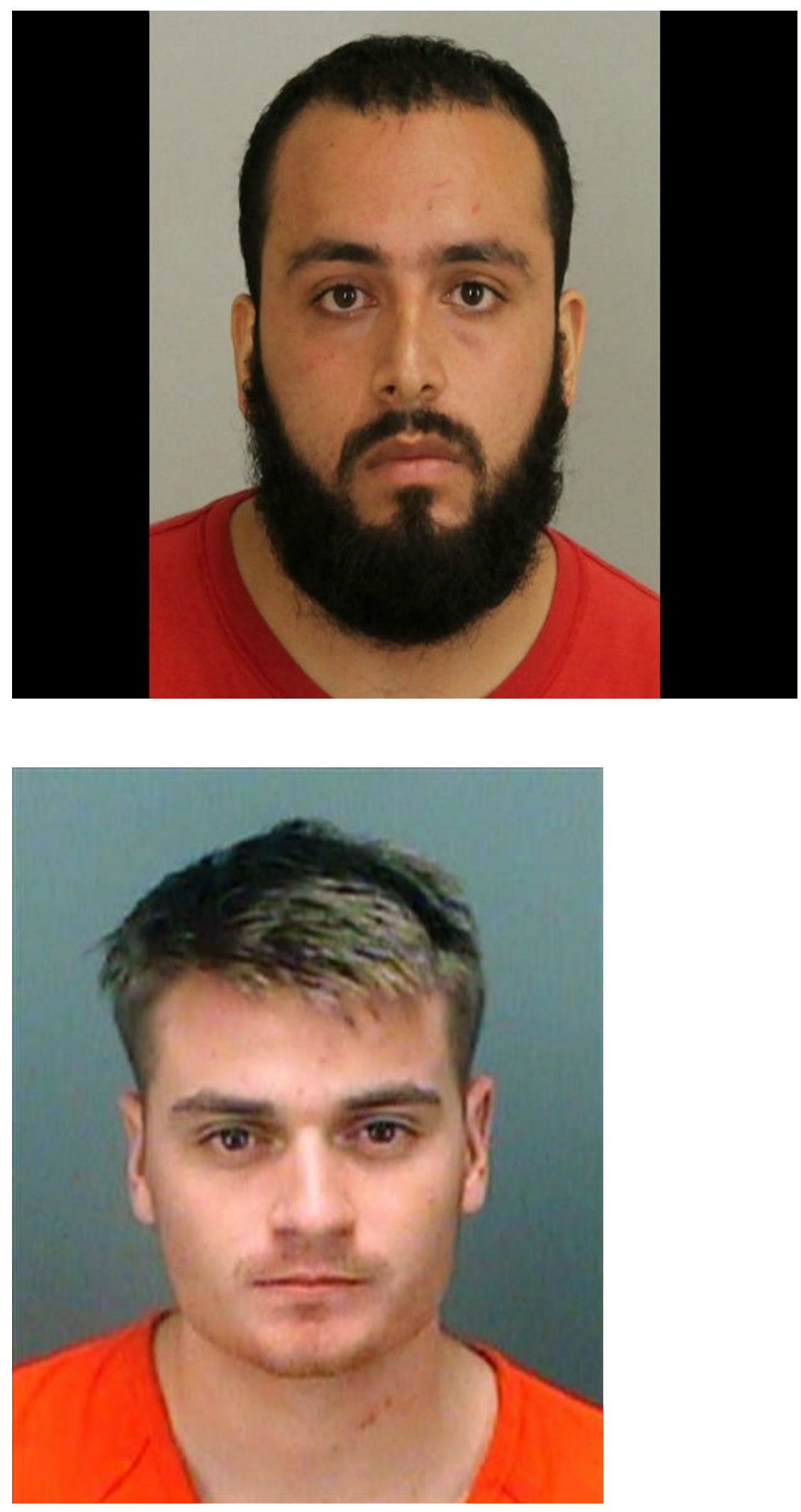
Appendix B: Survey Instrument

\section{[MANIPULATION]}

[POST TEST FEAR AND LAW ENFORCEMENT: FOUR QUESTIONS]

We would like to know your views about the article you just read.

How would you rate the likelihood of an attempted act of mass violence such as the one described in the news article, occurring in the next 12 months?

\begin{tabular}{|l|l|l|l|l|l|l|}
\hline $\begin{array}{l}\text { Extremely } \\
\text { Unlikely }\end{array}$ & \multicolumn{9}{|c|}{} & $\begin{array}{l}\text { Extremely } \\
\text { Likely }\end{array}$ \\
\hline 1 & 2 & 3 & 4 & 5 & 6 & 7 \\
\hline
\end{tabular}

To what extent are you worried about such an attack actually happening?

\begin{tabular}{|l|l|l|l|l|l|l|}
\hline $\begin{array}{l}\text { Not } \\
\text { Worried at } \\
\text { all }\end{array}$ & & & & & & \\
\hline 1 & 2 & 3 & 4 & 5 & 6 & 7 \\
\hline
\end{tabular}

How much do you agree or disagree with the following statement: the F.B.I. was right to organize the sting operation described in this article?

Strongly agree

Agree

Neither agree nor disagree

Disagree

Strongly disagree

How much do you agree or disagree with the following statement: the F.B.I's sting operation described in the article should be classified as entrapment (helping the suspect commit a crime)? Strongly agree

Agree

Neither agree nor disagree

Disagree

Strongly disagree

\section{[MANIPULATION CHECK: TWO QUESTIONS]}

What type of weapon was the potential attacker planning to use?

Nuclear weapon

Biological weapons

Explosives (conventional bombs)

Poisonous gas 
None of the above

What were the motivations for the defendant to attempt an act of mass violence?

\section{[RANDOMIZE]}

To be on the news

To catch the attention of white supremacist group

To catch the attention of Islamic terrorist group

To catch the attention of animal activist groups

To protest the commercialized holiday Black Friday

The next set of questions will ask about your views of terrorism in general. Remember that your responses will be kept completely confidential, so please answer honestly.

*For each statement, please indicate whether you strongly agree, agree, disagree, or strongly disagree. [Turn into two questions instead of a matrix in qualtrics]

The following questions will ask you about your views about your civil liberties, or personal freedoms. Remember your answers will be kept confidential, so please answer honestly.

*How concerned are you about the invasion of your personal privacy in the United States today? Are you very concerned, somewhat concerned, only a little concerned, or not at all concerned?

Very concerned

Somewhat concerned

Only a little concerned

Not concerned at all

*In order to curb terrorism in this country, do you think it will be necessary for the average person to give up some rights and liberties, or do you think we can curb terrorism without the average person giving up rights and liberties?

It will be necessary for the average person to give up some rights and liberties.

We can curb terrorism without the average person giving up rights and liberties.

Don't know.

*In order to reduce the threat of terrorism in the United States, would you support or oppose giving law enforcement broader authority to do the following things?

\begin{tabular}{|l|l|l|l|l|l|}
\hline & $\begin{array}{l}\text { Strongly } \\
\text { support }\end{array}$ & Support & $\begin{array}{l}\text { Neither } \\
\text { support nor } \\
\text { oppose }\end{array}$ & Oppose & $\begin{array}{l}\text { Strongly } \\
\text { oppose }\end{array}$ \\
\hline Wiretap telephones & & & & \\
\hline Intercept email & & & & & \\
\hline
\end{tabular}




\begin{tabular}{|l|l|l|l|l|l|}
\hline Examine internet & & & & \\
activities & & & & & \\
\hline Detain terrorist & & & & \\
suspects & & & & \\
indefinitely & & & \\
without charging & & & \\
them & & & \\
\hline
\end{tabular}

To what extent would you support or oppose new laws to strengthen to strengthen security measures against terrorism, even if it meant reducing privacy protections?

\begin{tabular}{|l|l|l|l|l|l|l|}
\hline $\begin{array}{l}\text { Strongly } \\
\text { oppose }\end{array}$ & & & & & & $\begin{array}{l}\text { Strongly } \\
\text { support }\end{array}$ \\
\hline 1 & 2 & 3 & 4 & 5 & 6 & 7 \\
\hline
\end{tabular}

To what extent would you be willing or unwilling to give up some of your personal freedom in order to reduce the threat of terrorism?

\begin{tabular}{|l|l|l|l|l|l|l|}
\hline $\begin{array}{l}\text { Very } \\
\text { unwilling }\end{array}$ & & & & & & Very willing \\
\hline 1 & 2 & 3 & 4 & 5 & 6 & 7 \\
\hline
\end{tabular}

You are almost finished. We just have a few background questions. These are for statistical analysis purposes only.

What is your age?

*Add drop down menu in Qualtrics*

With what gender do you identify?

Male

Female

Other, please specify

What is your race/ethnicity?

Black, African, Caribbean

Caucasian, White, European

Central Asian / Arab

East Asian (Chinese, Japanese, Korean, Taiwanese, etc.)

South Asian (Indian, Pakistani, Bangladeshi, etc.) 


\section{Other [Specify]}

What is the highest level of education you have completed?

Less than high school

High school

Associate's degree

Bachelor's degree

Master's degree

Professional degree/Doctorate

Have you ever been the victim of a violent incident?

Yes

No

Prefer not to answer

How old are you?

How would you describe your political ideology?

\begin{tabular}{|l|l|l|l|l|l|l|}
\hline $\begin{array}{l}\text { Very } \\
\text { conservative }\end{array}$ & & & & & & Very liberal \\
\hline 1 & 2 & 3 & 4 & 5 & 6 & 7 \\
\hline
\end{tabular}

In politics today, do you consider yourself a Republican, a Democrat, an Independent, or something else?

Republican

Democrat

Independent

Something else, please specify: 